\title{
気体分離用無機膜のゾルーゲル法による製膜
}

\author{
草壁克己・前田英明・諸岡成治
}

\author{
九州大学工学部 応用物質化学科 焉 812 福岡市東区箱崎 6-10-1
}

\section{Preparation of Inorganic Membranes by Sol-gel Method for Gas Separation}

\author{
Katsuki Kusakabe, Hideaki Maeda, Shigeharu Morooka \\ Department of Chemical Science and Technology, Kyushu University, \\ 6-10-1 Hakozaki, Higashi-ku, Fukuoka 812, Japan
}

\begin{abstract}
Development of sol-gel derived porous ceramic membrane is reviewed from the standpoint of gas separation at high temperature. Amorphous silica membranes have attained both high hydrogen selectivity and permeability. However, $\gamma$-alumina membranes coated by Yoldas method have pores of 2-10 $\mathrm{nm}$ in size, and their hydrogen selectivity is relatively low due to the Knudsen diffusion mechanism. Modification of pores by impregnation of ultrafine particles or chemical vapor deposition improves the selectivity by the size of molecules. The interaction of molecules with pore walls is important for the separation of polar gases. Multicomponent oxide membranes are thermally and chemically stable at high temperature and have appreciable permeation properties.
\end{abstract}

Key words : inorganic membrane, gas separation, sol-gel method, permeability

\section{1.はじめに}

無機膜は耐熱性や化学的安定性に優れているために, 高温気体の分離膜として注目されているが, 所定の機能 を持つ無機膜を創製するには, 薄膜化と微細構造の制御 が必要である ${ }^{1)}$. 無機膜の作製法としては, 気相法, 塗 布熱分解法およびゾルーゲル法に代表される溶液法があ る. 中でもゾルーゲル法によるセラミック膜の表面修飾 について多くの研究が報告されている.

ゾルーゲル法 ${ }^{2.3)}$ は, 金属の有機および無機化合物 の溶液を出発原料之し, 溶液中での化合物の加水分解 ・ 重合によって, 金属酸化物あるいは水酸化物の微粒子が 溶解した状態 (ゾル) とし, さらに反応を進ませてゲル 化し, ゲルの加熱によって酸化物固体を生成する方法で ある. ゾルーゲル法を利用した気体分離用無機膜の作製
では, 多孔質基材をゲル中にディッピングするか, スピ ンコーティングによって表面に湿潤ゲルの薄層を形成さ せ, 乾燥・焼成して酸化物とする. 図 1 にシリカ膜を作 る場合の流れ図を示す.ゾルーゲル法の最大の特長は, セラミックスやガラスを低温で合成できることである. 製膜法としては, (1) 大面積化が容易, (2) 多成分薄膜の 作製とその組成制御が容易，(3) 特別な装置を必要とせ ず操作が簡単である, などの点から実用的である. 本稿 では, 最近発表されたゾルーゲル法によるセラミック膜 の作製法と, 得られた膜の気体透過特性について紹介す る.

\section{2. ゾルーゲル法による無機膜の作製}

ゾルーゲル法では, 出発原料として金属アルコキシド 


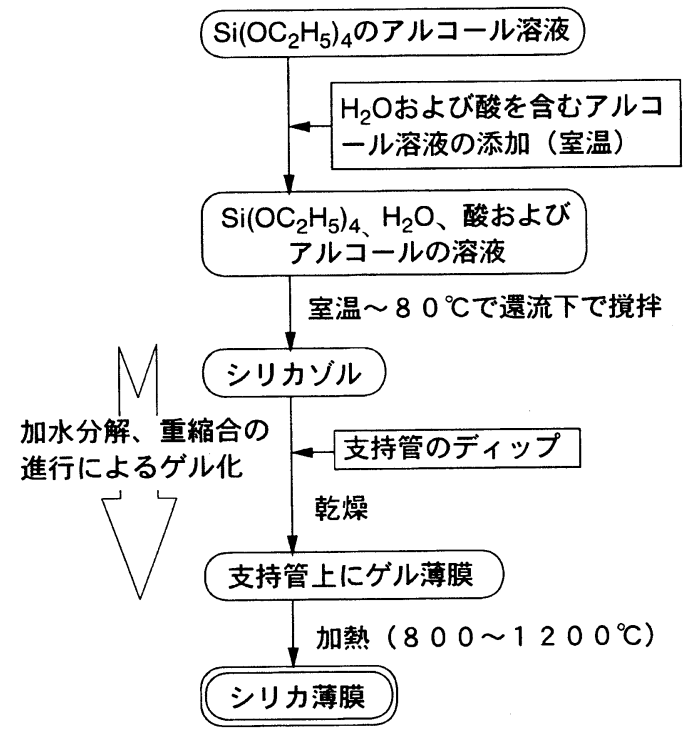

図 1. ゾルーゲル法によるシリカ膜の調製

$\left(\mathrm{M}(\mathrm{OR})_{n}, \mathrm{M}\right.$ は金属元素, $\mathrm{R}$ はアルキル基, $\mathrm{n}$ は金属元 素の酸化数）がしばしば使われる. 金属アルコキシドは アルコール等の溶媒中で加水分解され, 続いて脱水ある いは脱アルコールによる重縮合反応を起こし，M-O-M 結合を持つ酸化物となる。

$$
\begin{aligned}
& \mathrm{M}(\mathrm{OR})_{n}+\mathrm{nH}_{2} \mathrm{O} \rightarrow \mathrm{M}(\mathrm{OH})_{n}+\mathrm{nROH} \\
& \quad \text { 加水分解 }) \\
& -\mathrm{M}-\mathrm{OH}+\mathrm{H}-\mathrm{O}-\mathrm{M} \rightarrow-\mathrm{M}-\mathrm{O}-\mathrm{M}+\mathrm{H}_{2} \mathrm{O} \\
& \quad \text { 脱水 }) \\
& -\mathrm{M}-\mathrm{OH}+\mathrm{R}-\mathrm{O}-\mathrm{M} \rightarrow-\mathrm{M}-\mathrm{O}-\mathrm{M}+\mathrm{ROH} \\
& \quad \text { 脱アルコール })
\end{aligned}
$$

この酸化物は多くの残留 $\mathrm{OH}$ 基を含んでおり, 反応 の初期では溶液中に溶解してゾルの状態にある. さらに 重縮合が進むと系全体が固化してゲルとなる．均質性に 優れた薄膜を作製するためには, ゾルの段階で均一化す る必要がある. 金属アルコキシドは極めて加水分解され やすいので，加水分解とそれに続く重合の速度を制御す ることが均一なゾルを作製するポイントになる。これら の速度は金属アルコキシドと溶媒の種類, 溶液の $\mathrm{pH}$, 反 応温度などによって決まる.ここでは加水分解速度を調 整するための方法として, 錯形成を伴うゾル-ゲル法 ${ }^{4}$ について述べる．ジオールなどの有機多座配位子と金属 アルコキシドは, 次に示す配位子交換反応を行う.

$$
\mathrm{M}(\mathrm{OR})_{n}+\mathrm{xHOR} \mathrm{OH}^{\prime} \mathrm{M}(\mathrm{OR})_{n-x}\left(\mathrm{OR}^{\prime} \mathrm{OH}\right)_{x}
$$$$
+\mathrm{xROH} \text { (配位子交換) }
$$

一般に, 多座配位子はより安定な錯体を形成し, 金属 アルコキシドの急激な加水分解反応を制御する効果があ る.

$$
\begin{aligned}
& \mathrm{M}(\mathrm{OR})_{n-x}\left(\mathrm{OR}^{\prime} \mathrm{OH}\right)_{x}+\mathrm{nH}_{2} \mathrm{O} \rightarrow \\
& \mathrm{M}(\mathrm{OH})_{n}+(\mathrm{n}-\mathrm{x}) \mathrm{ROH}+\mathrm{xHOR} \mathrm{HOH}^{\prime} \mathrm{OH} \\
& \quad \text { (加水分解) }
\end{aligned}
$$

この方法は複合酸化物の薄膜を作製する場合に特に有 効である. 2 種の金属アルコキシドを含む溶液に水を加え ると, どちらかのアルコキシドの加水分解速度が速いの で, その酸化物が先に生成する, そのため, 均一性の悪 いゾルとなる.一方, 錯形成を伴うゾル - ゲル法では, 異種の金属アルコキシドをジオールで架橋した錯体 $\left(-\mathrm{M}-\mathrm{OR}-\mathrm{M}^{\prime}-\right)$ が形成され, 加水分解により異種の金 属元素が分子オーダーで分散したゾルとなる. ジオール のほか, アセチルアセトンや $\beta$ - ジケトン等を加える場 合もある.

基板上にゾル薄膜を形成した後の乾燥段階で割れが起 きるときには, ゾルに有機高分子を添加して粘度を高く すれば，ゲル膜が柔軟になり割れを防ぐことができる.

\section{3. シリカ膜の作製と気体透過性}

塩基を触媒として $\mathrm{Si}(\mathrm{OR})_{4}$ を加水分解すると, 単量 体が完全に分解し 3 次元的に重縮合するので, 多くの架 橋結合が生じて大きな Si-O クラスターとなり,これが 集まってゲルとなる. Si に比べて Tip Z $\mathrm{r}$ のアルコキ シドは加水分解速度が速く, 水を加えただけで同様の現 象が起こり, 生成粒子が大きくなる.

3 次元クラスターの生成（加水分解速度》重縮合速度 の場合)

$$
\begin{aligned}
& \mathrm{nSi}(\mathrm{OR})_{4}+4 \mathrm{nH}_{2} \mathrm{O} \rightarrow \mathrm{nSi}(\mathrm{OH})_{4}+4 \mathrm{nROH} \\
& \mathrm{nSi}(\mathrm{OH})_{4} \rightarrow \mathrm{nSiO}_{2}+2 \mathrm{nH}_{2} \mathrm{O}
\end{aligned}
$$

一方, シリカに酸性溶液を加えると, 加水分解が起こ りながら重縮合が進むので，架橋結合を生じる割合が少 なくなり，小さなクラスターが連結した線状の“高分子 ゾル”となりやすい，これをゲル化して乾燥・焼成すれ ば小さな粒子が得られる.

1 次元クラスターの生成（加水分解速度＜重縮合速度 の場合)

$$
\mathrm{Si}(\mathrm{OR})_{4}+\mathrm{H}_{2} \mathrm{O} \rightarrow \mathrm{Si}(\mathrm{OR})_{3}(\mathrm{OH})+\mathrm{ROH}
$$




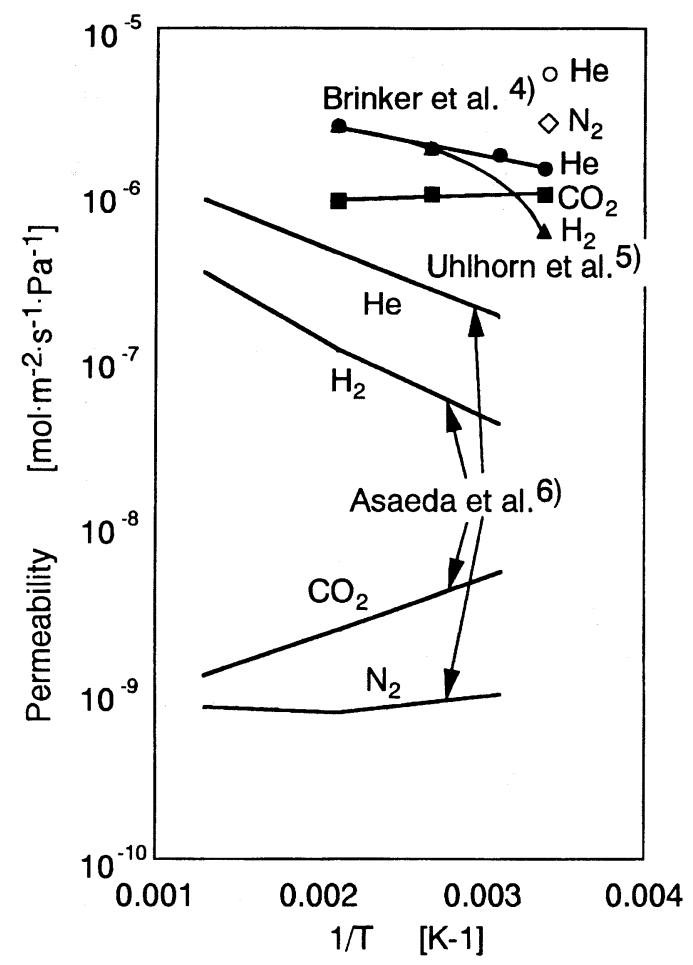

図 2. ゾルーゲル法で作製したシリカ膜の気体透 過速度

$(\mathrm{OR})_{3} \mathrm{Si}-\mathrm{O}-\mathrm{Si}(\mathrm{OR})_{2}(\mathrm{OH})+2 \mathrm{ROH} \quad(9)$

$(\mathrm{OR})_{3} \mathrm{Si}-\mathrm{O}-\mathrm{Si}(\mathrm{OR})_{2}(\mathrm{OH})$

$+\mathrm{Si}(\mathrm{OR})_{4}+\mathrm{H}_{2} \mathrm{O} \rightarrow$

$(\mathrm{OR})_{3} \mathrm{Si}-\mathrm{O}-\mathrm{Si}(\mathrm{OR})_{2}-\mathrm{O}-\mathrm{Si}(\mathrm{OR})_{2}(\mathrm{OH})$

$+2 \mathrm{ROH}$

$(\mathrm{OR})_{3} \mathrm{Si}-\left[\mathrm{O}-\mathrm{Si}(\mathrm{OR})_{2}\right]_{n}-\mathrm{O}-\mathrm{Si}(\mathrm{OR})_{2}(\mathrm{OH})$

$+\mathrm{Si}(\mathrm{OR})_{4}+\mathrm{H}_{2} \mathrm{O} \rightarrow$

$(\mathrm{OR})_{3} \mathrm{Si}-\left[\mathrm{O}-\mathrm{Si}(\mathrm{OR})_{2}\right]_{n+1}-\mathrm{O}-\mathrm{Si}(\mathrm{OR})_{2}(\mathrm{OH})$

$+2 \mathrm{ROH}$

ゾルーゲル法で製膜する場合には，構成粒子が小さい ほど細孔径が小さくなるので, ミクロポアを有する膜を 作製するにはシリカゾルが適している.

Brinker ${ }^{5)}$ はテトラエチルシリケート (TEOS) のエ タノール溶液を出発原料とし, 酸を用いた 2 段階加水分 解法によりシリカゾルを調製した. 小角X線散乱によっ てゾルの構成を解析し，大きさは $0.26 \sim 0.52 \mathrm{~nm}$ であ ることを示した. このゾルをディップ法により $\gamma$-アル ミナ支持管表面に積層し, 空気中で $400^{\circ} \mathrm{C}$ で焼成した.
アルミニウムイソプロポキシド

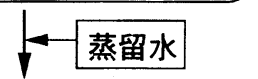

加水分解 (348K，24 時間)

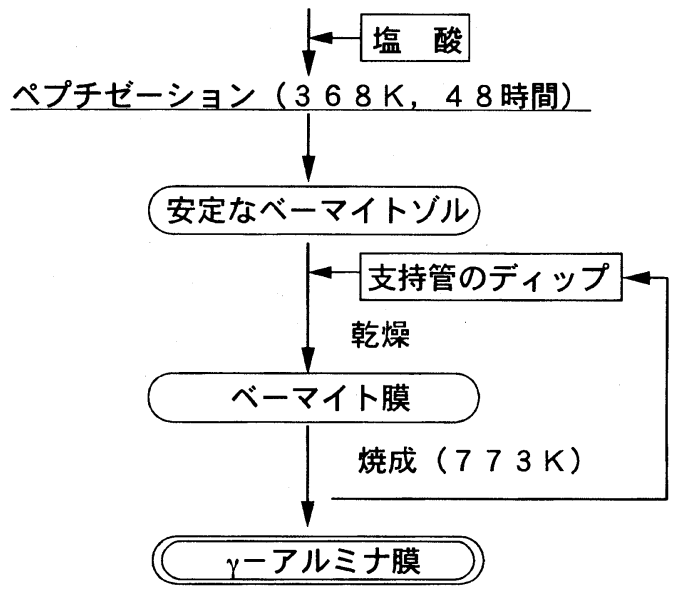

図 3. Yoldas 法による $\gamma$-アルミナ膜の調製

TEM による断面観察から膜厚は 10〜 $120 \mathrm{~nm}$ であっ た. また, 窒素の吸脱着特性を測定した結果から，その 細孔径は $1 \mathrm{~nm}$ 以下であると推定した. 図 2 に示すよう に, Brinker ら ${ }^{5)}$ の膜は透過速度が速く, また窒素に対す るへリウムの透過速度比が 1.5 2.2 となって, Knudsen 拡散の理論值 (2.6) よりも小さい. したがって, 彼らの 膜には漏れやピンホールがあると推定される.ゾル-ゲ ル法による製膜では，ゾルを理想的に作成しても成膜技 術が不十分であれば，期待する透過特性を得られないこ とが多い. Uhlhorn ら ${ }^{6)}$ も TEOSを出発原料として, $\gamma$-アルミナ支持管上にシリカ膜を形成させた. He の 透過速度は $\mathrm{H}_{2}$ に比べて速く, また, Knudsen 透過機 構の傾向と異なり, $\mathrm{He}$ と $\mathrm{H}_{2}$ の透過速度は温度の上昇 と共に速くなった（図 2).このことから, 彼らの膜に ついては細孔壁と透過気体分子間に相互作用が強く働い ていると考えられる. Asaeda ら ${ }^{7)}$ は, 平均細孔径が 1 $\mu \mathrm{m}$ の $\alpha$-アルミナ管表面に 4 種類のシリカゾルを用い て，特殊な製膜法によりピンホールの無いシリカ膜を形 成している. 図 2 で明らかなように, $\mathrm{He}, \mathrm{H}_{2}$ の透過速 度は $10^{-6} \sim 10^{-7} \mathrm{~mol} \cdot \mathrm{m}^{-2} \cdot \mathrm{s}^{-1} \cdot \mathrm{Pa}^{-1}$ で, $\mathrm{N}_{2}$ に対する $\mathrm{He}, \mathrm{H}_{2}$ の透過速度比が約 100 倍以上の膜が形成されて いる．支持管の細孔径が大きいことを考えると，その製 膜技術には見るべきものがある.

このように, 水素選択分離用としてのシリカ膜は, 透 


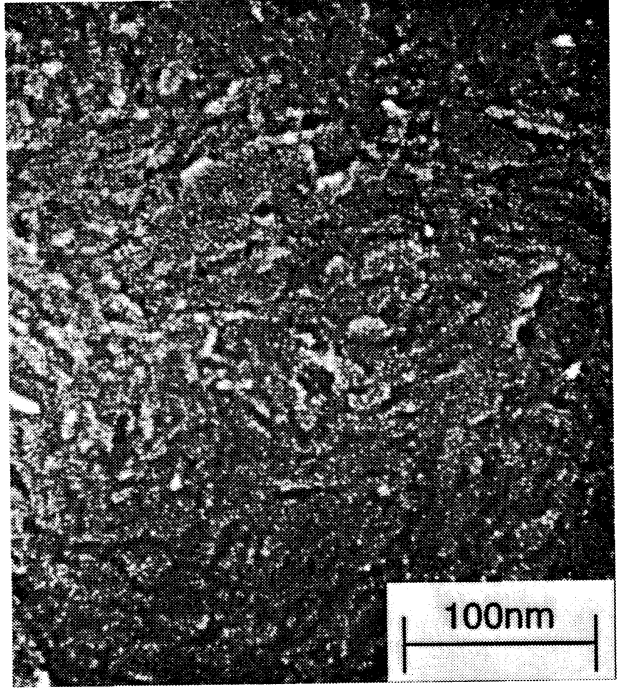

(a) ベーマイト膜

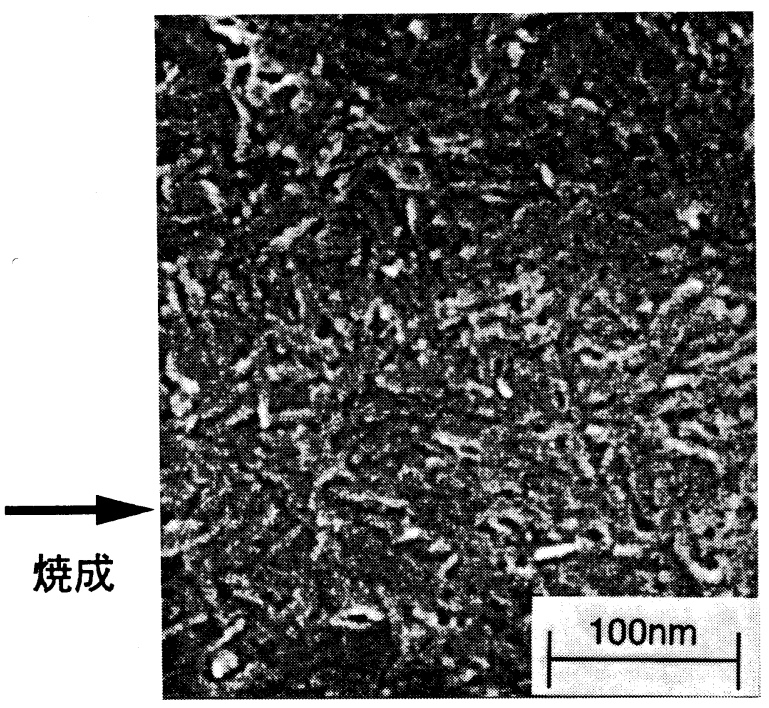

(b) $\gamma$-アルミナ膜

図 4. ベーマイト膜および $\gamma$-アルミナ膜表面の SEM 像 ${ }^{11}$

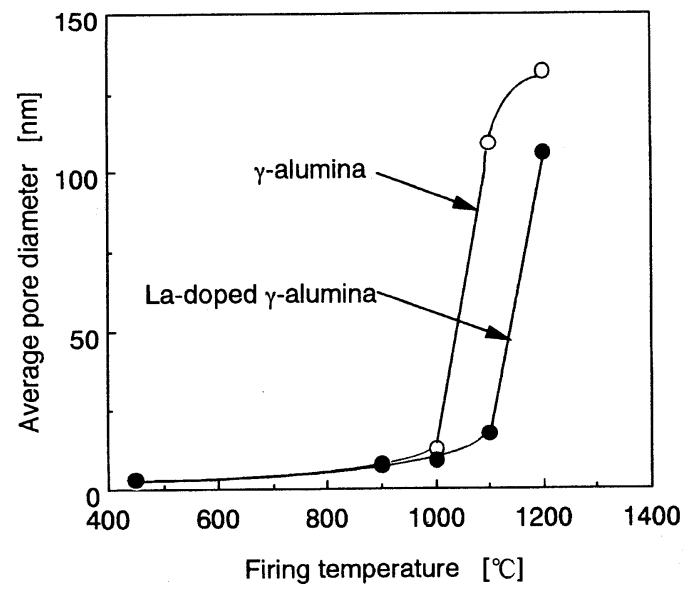

図 5. $\gamma$-アルミナ膜の細孔径に及ぼす焼成温度の 影響（焼成時間 : 30 時間）

過速度，分離性の点では完成された感がある.ただし， ゾルーゲル法によるシリカ膜は, 高温の水蒸気と長時間 接触したときに緻密化してクラックを生じる恐れがあ る. CVD 法では支持管の細孔内にシリカ膜を形成させ て耐水蒸気性を改善したという報告8.9) があり, ゾルゲル法で成膜したシリカ膜についても，この点をさらに 検討する必要があろう.

\section{4. アルミナ膜の作製と気体透過性}

ゾルーゲル法による多孔質アルミナ膜は, Yoldas ${ }^{10)}$ らによって開発された方法で作製されることが多い，製 膜のフローチャートを図 3 に示す．アルミニウムイソプ ロポキシドやブトキシドを熱水で加水分解し，次に酸で 解膠してゾル溶液を作り, これを多孔質支持体に塗布し て乾燥すると, ベーマイトゲルの薄膜が得られる．この

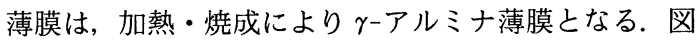
4 はベーマイトゲル膜と $\gamma$-アルミナ薄膜の表面の高分 解能 SEM 写真 ${ }^{11}$ である. 焼成の前後においても表面 の微細構造はほとんど変化しない. Leenaars ら ${ }^{12)}$ は ベーマイトゲル膜は平板上の結晶を積み重ねたカード構 造であると推定しているが確証はない. ゾル形成の条件 によって構造が变化する可能性もある. 気体分離膜とし て報告された $\gamma$-アルミナ膜の細孔径は $2 \sim 10 \mathrm{~nm}$ の範 囲にあり，気体透過機構からみれば Knudsen 拡散域に ある．そのため，例えば窒素に対する水素の分離係数は 3.7 が上限となる。図 5 は $\gamma$-アルミ膜の細孔径に及ぼす 焼成温度の影響を示す ${ }^{13)}$. 焼成温度が高くなると細孔 径が増大し, $1,000-1,200{ }^{\circ} \mathrm{Cで}$ 焼成すれば相変化を起こ して $\alpha$-アルミナとなる. 一方, ベーマイトゾルにモル 比で約 $3 \%$ の硝酸ランタンを加え焼成すると, 酸化ラン タンやランタンアルミネートが形成され, 粒成長が防止 される ${ }^{14)}$ 図 5 に示すように, ランタン担持 $\gamma$-アルミナ 


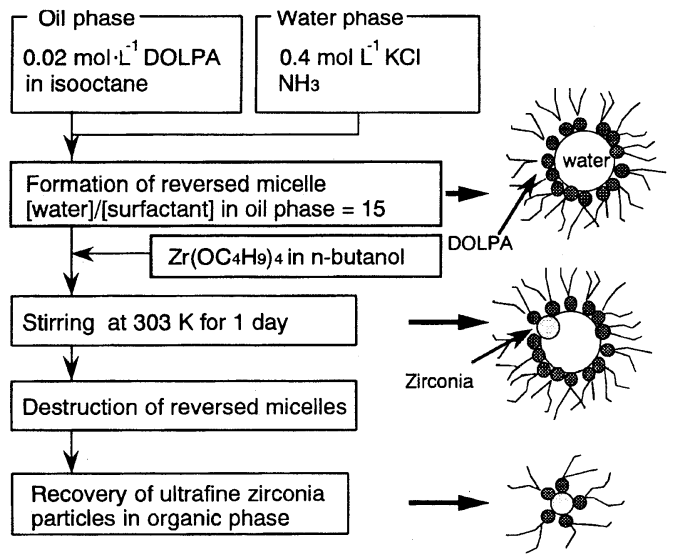

図 6. 逆ミセル法によるジルコニア超微粒子の生 成手順 ${ }^{15)}$

膜では細孔径の増大が抑制される.

$\gamma$-アルミナの細孔径をさらに小さくすることによっ て, 分子小るい性を実現できれば, 水素に対する分離特 性が向上する，超微粒子を合成し，それを用いて細孔を 埋めて細孔径を抑制する方法, 気相析出法 (CVD 法) によって $\mathrm{SiO}_{2}$ や $\mathrm{ZrO}_{2}$ を細孔内に析出させる方法など が試みられている15 17). Yamaki ら ${ }^{15)}$ は油溶性界面 活性剤ジオレイルリン酸 (DOLPA) を用いて逆相ミセ ルを形成し，ジルコニウムテトラブトキシドのブタノー ル溶液を加えて, 逆相ミセル内の微小水滴中で加水分解 反応を行い, ジルコニア超微粒子を得た. 酸を加えて逆 相ミセル破壊後, 油相中で DOLPA と共存するジルコ ニア超微粒子のサイズを測定したところ, 平均径が 2 $\mathrm{nm}$ であった. 図 6 は超微粒子合成のフローチャートで ある. 油相中のジルコニア超微粒子は分散性がよく, 粒 径が細孔径よりも小さいので, $\gamma$-アルミナ膜内に強制吸 引し, 乾燥後焼結した。 この吸引, 乾燥そして焼結の操 作を複数回繰り返し, 気体の透過特性を測定した. 6 回 の繰り返しを行った膜の窒素に対する水素の選択透過係 数は, Knudsen 值の 3.7 を上回り 4.5 となった.

$\gamma$-アルミナ膜の分離特性を改善するには, 膜に第 2 成 分の金属あるいは金属酸化物を加え修飾する方法もあ る. 細孔壁と着目する気体成分との相互作用が生じれば, 表面拡散による透過が期待できる. Uhlhorn ら ${ }^{18)}$ は二 酸化炭素の吸着性を向上するために $\gamma$-アルミナに $\mathrm{MgO}$ を担持した膜を調製し，二酸化炭素の透過特性を測定し た.この膜では吸着した二酸化炭素の mobility が減少 したために, 二酸化炭素の選択透過性は $\gamma$-アルミナ膜

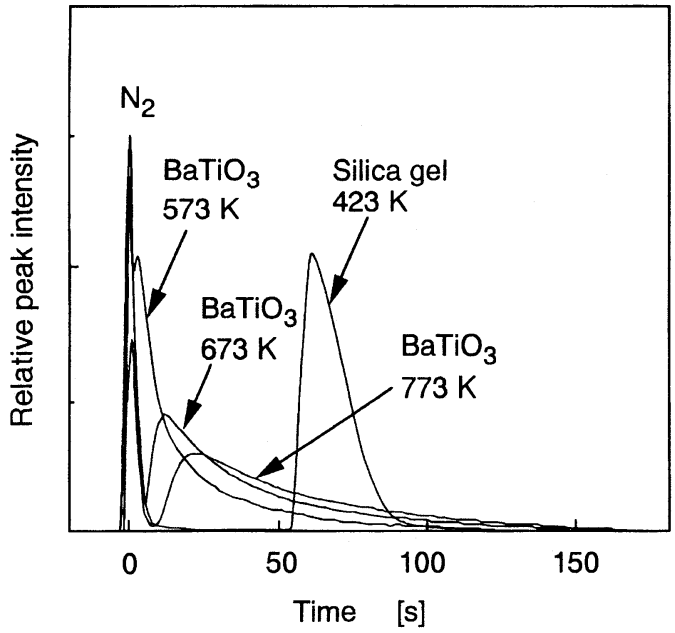

図 7. $\mathrm{BaTiO}_{3}$ 粒子を充填したカラムを用いた二 酸化炭素のインパルス応答 $\left.{ }^{27}\right)\left(\mathrm{N}_{2}\right.$ の滞留 時間を 0 とする.）

に比べて低下した. Okubo ら ${ }^{19)}$ はニッケルを含有した ベーマイトゾルを用いて成膜したが, ピンホールを完全 に解消することはできなかった. Uhlhorn ら ${ }^{18)}$ は $\gamma-$ アルミナ薄膜を $1.5 \mathrm{~mol} ・ \mathrm{~L}^{-1}$ の硝酸銀と $3 \mathrm{~mol} ・ \mathrm{~L}^{-1}$ の尿素溶液に含浸し, $90^{\circ} \mathrm{C}$ で反応させた後, 水素中で $450^{\circ} \mathrm{C}$ で焼成して銀粒子とした.このサイクルを 10 回 繰り返すことによって, $18 \mathrm{wt} \%$ の銀を析出した，その 結果, 窒素に対する水素の透過速度比は Knudsen 理論 値を超え, 最大 8.8 となった. Eguchi らは20.21) 同様 の方法により水素の吸着性がある白金族金属 $(\mathrm{Pd}, \mathrm{Pt}$, $\mathrm{Rh}, \mathrm{Ru})$ を $\gamma$-アルミナに分散させた膜を調製した.

\section{5. 多成分および複合膜の作製と気体透過性}

シリカ, アルミナ, チタニア, ジルコニア等の酸化物 を複数種含む膜は, ダブルアルコキシドを用いたり，錯 形成を伴うゾル - ゲル法によって作製することができ る. シリカーアルミナ複合膜による凝縮性気体の選択的 透過に関しては, Asaeda ら 22.23) の研究がある. 大矢 らは24. 25) TEOS に酸化ホウ素を加えた溶液を出発原 料として多孔質ガラス膜を作製し, 高温におけるメタン, 二酸化炭素混合気体の分離や, 水素-水蒸気系からの水 の選択透過について検討した. また, 高温, 高腐食条件 の中で使用可能な気体分離膜として, ゾルーゲル法によ り $\mathrm{SiO}_{2}-\mathrm{ZrO}_{2}-\mathrm{Y}_{2} \mathrm{O}_{3}$ 複合膜を作製した ${ }^{26)} こ の$ 膜を用 いて $\mathrm{H}_{2}-\mathrm{H}_{2} \mathrm{O}-\mathrm{HBr}$ 混合気体の分離特性を調べた. $\mathrm{H}_{2}$ 
は膜を透過せず, $\mathrm{HBr}$ が $\mathrm{H}_{2} \mathrm{O}$ に比べて 2 倍の速度で選 択的に透過することを示した。

Kusakabe ら 27) は, バリウムとチタンのイソプロポ キシドを加水分解したのち, 窒素中 $600^{\circ} \mathrm{C}$ で焼成して, 高い比表面積 (42〜 $\left.47 \mathrm{~m}^{2} \cdot \mathrm{g}^{-1}\right)$ を有するチタン酸バリ ウム粒子を合成した。この粒子は高温 $\left(\sim 500^{\circ} \mathrm{C}\right)$ にお いても $3 \mu \mathrm{mol} \cdot \mathrm{m}^{-2}$ 以上の二酸化炭素を吸着した. この粒子をガスクロの分離カラムに充填し, 二酸化炭素 のインパルス応答実験を行ったところ, 図 7 に示すよう に吸着した二酸化炭素は mobile であることがわかっ た．アルコキシドを加水分解した後に酶酸を用いて解膠 すると安定なチタン酸バリウムゾルが得られるので，こ のゾルをを $\alpha$-アルミナ管にディップコーティングして 焼成し薄膜とした，この膜は二酸化炭素を表面拡散に よって選択的に分離する能力があった。このように，無 機膜を複合化することによって, 表面拡散による分離や 而熱性や耐腐食性の向上が期待できる.

\section{6. おわりに}

気体分離（特に二酸化炭素や酸素の選択分離膜）を目 的とした無機膜の創製に当たっては,ナノサイズの構造 制御と機能性を持たせるための複合化が重要である。こ のような膜の製造法としてはゾル-ゲル法が有効である が，多成分の金属アルコキシドを含む溶液中の反応過程 や，ゲル中に機能性を有する無機コロイド粒子や金属イ オンを導入した場合の安定性の問題など, 解明すべき課 題も多い，無機膜プロセスを工業化するには，(1) 膜の 選択透過性と透過速度の向上，(2) 膜の大面積化とモ ジュール化, (3) 機械的強度と化学的安定性の向上, (4) 簡単で低コストの製造法の開発，が重要であろう。

\section{文献}

1) S. Morooka, K. Kusakabe and T. Yamaki : FC Report, 11, 9 (1993)

2) C. J. Brinker and G. W. Scherer : Sol-gel Science, Academic Press Inc., San Diego, (1990)

3）作花済夫：ゾル-ゲル法の科学,アグネ承風社, (1988)

4) F. Mizukami, S. Niwa, M. Toba, T. Tsuchiya, K. Shimizu, S. Imai, J. Imamura : Preparation of Catalysis, Vol.31, B. Delmon, P. Grang, P. A. Jacobs and G. Poncelet, Eds., Elsevier, p. 45 (1987)

5) C. J. Brinker, T. L. Ward, R. Sehgal, N. K. Raman, S. L. Hietala, D. M. Smith, D.-W. Hua and T. J. Headley: J. Membrane Sci.,
77, 165 (1993)

6) R. J. R. Uhlhorn, K. Keizer and A. J. Burggraaf : J. Membrane Sci., 66, 271 (1992)

7) M. Asaeda, Y. Oki and T. Manabe : Priority-Area Research Supported by the Ministry of Education, Science and Culture, Japan, Energy Conversion and Utilization with High Efficiency, Subarea C, 1993 Research Report, 253 (1993)

8) M. Tsapatsis and G. Gavalas : J. Memb, Sci., 87, 281 (1994)

9) S. Yan, H. Maeda, K. Kusakabe and S. Morooka : Ind. Eng. Chem. Res., in press.

10) B. E. Yoldas, Am. Ceram. Bull., 54, Soc. 289 (1975)

11) T. Okubo, M. Watanabe, K. Kusakabe and S. Morooka : J. Materials Sci., 25, 4822 (1990)

12) A.F.M. Leenaars, K. Keizer and A. J. Burggraaf : J. Mat. Sci., 19, 1077 (1984)

13) Y.-S. Lin and A. J. Burggraaf : J. Am. Ceram. Soc., 74, 219 (1991)

14) M. Chai, K. Sekizawa, M. Machida, K. Eguchi and H. Arai : Nippn Seramikkusu Kyokai Gakujutsu Ronbunshi, 99, 530 (1991)

15) T. Yamaki, H. Maeda, K. Kusakabe and S. Morooka : J. Membrane Sci., 85, 167 (1993)

16) Y.-S. Lin and A.J. Burggraaf : AIChE J., 38, 445 (1992)

17) Y.-S. Lin and A. J. Burggraaf : J. Membrane Sci., 79, 65 (1993)

18) R. J. R. Uhlhorn, K. Keizer and A. J. Burggraaf : J. Membrane Sci., 46, 225 (1989)

19) T. Okubo, M. Watanabe, K. Kusakabe and S. Morooka : J. Materials Sci. Lett., 12, 188 (1993)

20) K. Eguchi, M.-R. Chai, Y. Yamashita, M. Machida and H. Arai : Stud. Surf. Sci. \& Catal., Vol. 77, "New Aspects for Spillover Effect in Catalysis", Elsevier Science Publishers B. V., 195 (1993)

21) M.-R. Chai, M. Machida, K. Eguchi and H. Arai : Chem. Lett., 979 (1992)

22) M. Asaeda and L. D. Du. : J. Chem. Eng. Japan, 19, 72 (1986)

23) M. Asaeda, L. D. Du. and M. Fuji : J. Chem. Eng. Japan, 19, 84 (1986)

24) M. Niwa, H. Ohya, Y. Tanaka, N. Yoshikawa, K. Matsumoto and Y. Negishi : J. Membrane Sci., 39, 301 (1988)

25) H. Ohya, S. Sato, A. Ishii, Y. Negishi and K. Matsumoto: Membrane, 15, 72 (1990)

26) H. Ohya, T. Hisamatsu, H. Fujimoto, S. Sato and Y. Negishi : Key Engng. Materials, 61 \& 62353 (1991)

27) K. Kusakabe, K. Ichiki and S. Morooka : J. Membrane Sci., in press.

（受付 1994 年 4 月 4 日） 